\title{
PERANAN ETIKA TUTUR BAHASA INDONESIA DALAM PEMBELAJARAN DI SEKOLAH
}

\author{
Umar Mansyur \\ Fakultas Sastra, Universitas Muslim Indonesia \\ umar.mansyur@umi.ac.id
}

\begin{abstract}
Abstrak
Pembelajaran bahasa Indonesia di sekolah diarahkan pada peningkatan keterampilan berbahasa siswa, baik dari aspek mendengarkan, berbicara, membaca, maupun menulis. Berbicara merupakan salah satu keterampilan berbahasa yang rentan dalam hubungannya dengan etika bertutur. Etika bahasa merupakan suatu kaidah normatif penggunaan bahasa yang menjadi pedoman umum yang disepakati oleh masyarakat pengguna bahasa bahwa cara yang demikian itu diakui sebagai bahasa yang sopan, hormat, dan sesuai dengan tata nilai yang berlaku dalam masyarakat. Seseorang yang terampil berbicara pasti mempertimbangkan apa yang akan dikatakan sebelum berbicara. Tidaklah salah jika pepatah mengatakan bahwa bahasa adalah cermin pribadi seseorang. Ungkapan tersebut menunjukkan bahwa kepribadian seseorang dapat dinilai dari tutur katanya dalam berbahasa. Bagi orang banyak, tutur kata yang baik, lemah-lembut, sopan-santun, akan mencitrakan seseorang sebagai pribadi yang baik dan berbudi pekerti luhur. Sebaliknya, tutur kata yang kasar dan buruk akan menimbulkan citra buruk pula pada pribadi orang tersebut. Atas dasar hal itu, etika tutur bahasa Indonesia memiliki peranan penting dalam pembelajaran di sekolah yang juga memberi kontribusi pada kurikulum pendidikan karakter siswa.
\end{abstract}

Kata kunci : Etika tutur, pembelajaran bahasa Indonesia

\section{Pendahuluan}

Tujuan berkomunikasi berkaitan erat dengan pilihan ragam bahasa yang digunakan. Tujuan tutur untuk mendidik, merayu, memarahi, meminta tolong, menyanjung, dan sebagainya, mengandung pilihan kata yang berbeda-beda. Dalam sebuah percakapan antara dua orang atau lebih ada aturan mengenai cara membuka percakapan, kapan harus berbicara, cara menyela, dan cara menutup percakapan, secara baik. Siapa partisipan yang diajak berbicara menentukan pilihan kata sapaan dan ragam tutur. Faktor penentu pemilihan bahasa dari segi partisipan tersebut dapat berupa umur, jabatan organisasi, silsilah keluarga, status sosial, pendidikan, dan bahkan ada gejala tingkat kekayaan juga mempengaruhi pilihan kata dalam berbahasa. 
Suasana pembicaraan, seperti marah, merayu, bahagia, sedih dan sebagainya, menjadi pertimbangan dalam memilih kata atau ragam bahasa yang sesuai. Penggunaan alat komunikasi, seperti telepon, surat, telegram, faksimile, dan sejenisnya juga menentukan cara dan ragam bahasa yang dipergunakan. Selain itu, norma sosial yang berlaku di masyarakat, seperti agama dan adat istiadat, berpengaruh terhadap etika bertutur sapa. Untuk itu, penutur perlu mempertimbangkan ragam bahasa yang akan digunakan, sesuai dengan kebutuhan. Aturan di atas berlaku pula dalam sopan santun berbahasa Indonesia dan sudah merupakan prinsip umum.

Menurut Hymes (dalam Sukatman, 2012), apabila seseorang berbahasa perlu mempertimbangkan hal-hal tertentu, antara lain (1) latar dan suasana pembicaraan, (2) siapa peserta wicaranya (orang pertama, kedua, atau bahkan ketiga), (3) tujuan pembicaraan yang jelas, (4) urutan, aturan, atau giliran wicara (cara menyela secara benar), (5) topik pembicaraan sesuai, (6) alat atau saluran wicara yang digunakan (telepon, surat, telegram dan sebagainya mempunyai aturan tersendiri), (7) norma atau sopan santun berbahasa yang berlaku di masyarakat bahasa yang bersangkutan, dan (8) ragam bahasa yang tepat (resmi, santai, ilmiah, dan sebagainya).

Sesungguhnya bahasa akan indah diucapkan dan manis untuk didengar jika bahasa diucapkan dengan baik dan juga beretika. Bangsa Indonesia sejak lama dikenal sebagai bangsa yang ramah dalam bertutur. Dunia internasional telah mengakui hal itu karena bangsa kita sangat menjunjung tinggi etika, baik dalam berbahasa, bersikap, maupun dalam bertingkah laku. Hal inilah yang patut dilestarikan dan diwariskan kepada para siswa, khususnya dalam proses pembelajara di sekolah.

Sejarah mencatat bahwa Presiden Soekarno mampu 'menghipnotis' para pendengarnya karena ketika beliau berpidato, pemilihan kata dan kalimatnya yang sangat bijak, intonasi dan nada suara yang indah, serta ekspresinya yang begitu memukau. Ini menjadi salah satu bukti bahwa bangsa Indonesia adalah bangsa yang beretika sejak lahirnya. Namun, pada kenyataanya di masa sekarang, tampaknya para siswa sudah tidak lagi memegang prinsip-prinsip keteladan tersebut di atas.

Dapat kita lihat berbagai kasus yang ditampilakan oleh media pemberitaan cetak maupun elektronik. Sebut saja kasus pemukulan yang dilakukan oleh seorang 
siswa kepada guru, caci maki oleh banyak siswa di media sosial, dan masih banyak lagi. Ada beberapa faktor yang menyebabkan terjadinya kemorosotan etika dalam berbahasa dewasa ini, seperti faktor perkembangan teknologi yang semakin pesat, kebebasan media massa, dan juga prinsip demokrasi yang selalu dijadikan dasar berpikir.

Pada konteks yang lain, menurut Mansyur (2016) Indonesia dikenal dengan bangsa yang ramah dan berbudi pekerti luhur, baik dalam berperilaku maupun dalam bertutur. Namun, akhir-akhir ini, pengaruh media sosial tampaknya juga berefek pada memudarnya etika dalam bertutur di tengah masyarakat. Sudah sering kita baca dan saksikan, banyak kalangan yang menggunakan media sosial sebagai wadah untuk mengekspresikan kemarahan, tulisan-tulisan yang memuat konten pornografi dan provokasi. Oleh karena itu, sebagai bangsa yang memegang teguh prinsip kesantunan, bangsa Indonesia hendaknya tetap menjaga etika berbahasa dan tetap mengedepankan bahasa kritis tapi halus, bukan bahasa yang kasar. Peran media massa juga sangat diharapkan agar menjadi salah satu media pengajaran etika berbahasa pada masyarakat, khususnya kepada kalangan siswa yang kian terpengaruh budaya asing.

\section{Bahasa Tubuh}

Komunikasi menggunakan bahasa tubuh adalah suatu bentuk komunikasi untuk menyampaikan pesan dengan menggunakan berbagai simbol bahasa tubuh, seperti perilaku bahasa tubuh, simbol budaya, dan simbol sosial. Pada pembahasan ini, istilah perilaku bahasa tubuh dan komunikasi bahasa tubuh diartikan serupa karena setiap aktivitas komunikasi bahasa tubuh antarmanusia selalu melibatkan perilaku bahasa tubuh.

Bahasa tubuh memiliki karakteristik umum, antara lain: (a) sebagai cara manusia untuk mengekspresikan perasaan, (b) merupakan ekspresi perilaku seharihari, (c) makna komunikasi bahasa tubuh sangat tergantung pada konteks tertentu; (d) pesan bahasa tubuh mendahului pesan verbal, (e) bahasa tubuh lebih jujur dibandingkan dengan bahasa verbal, dan (f) komunikasi bahasa tubuh kadangkadang sulit untuk diinterpretasikan sehingga membutuhkan adanya pola interpretasi yang holistik (Muhammad, 1995). 
Bahasa tubuh manusia memiliki makna dan peran yang besar dalam komunikasi, meskipun selama ini bahasa verbal selalu dianggap sebagai alat komunikasi terandal dengan mengabaikan unsur-unsur nonverbal. Menurut Taufik (2003), bahasa tubuh mengandung tiga makna, antara lain: (1) makna personal, (2) makna sosiobudaya, dan (3) makna religius.

Makna personal terkait dengan pemakaian zona pembicaraan sebagai suatu cara untuk mengungkapkan perasaan yang bersifat pribadi. Zona wicara terbagi menjadi beberapa zona, seperti zona intim dekat, zona intim, zona pribadi, zona sosial, dan zona publik. Selanjutnya, makna sosial budaya bahasa tubuh terkait dengan konteks budaya etnis atau bangsa tertentu. Di beberapa negara, seperti Bulgaria, anggukan kepala malah berarti "tidak", sedangkan menggelengkan kepala berarti "ya". Selain itu, di Indonesia orang akan membungkukkan badan lebih rendah ketika berjabatan tangan dengan orang yang dihormati. Adapun makna religius bahasa tubuh terkait dengan komunikasi manusia dengan Sang Pencipta. Setiap agama mempunyai gerakan bahasa tubuh sesuai dengan kepercayaan dan keyakinan masing-masing yang sudah baku. Misalnya, umat Islam dalam melakukan salat, bahasa tubuhnya sesuai dengan tata tertib gerakan tubuh yang sudah ditentukan urutannya dalam rukun shalat (Taufik, 2006).

Selanjutnya, fungsi bahasa tubuh antara lain: (1) repetisi, yaitu mengulangulang kembali gagasan yang sudah disajikan secara verbal, seperti tanda setuju secara verbal dengan cara sambil mengangguk berkali-kali; (2) kontradiksi, yaitu penolakan atau memberi arti lain terhadap pesan verbal, seperti memuji dengan mencibirkan bibir; (3) aksentuasi, yaitu memberi penegasan terhadap pesan verbal, seperti menyatakan penyesalan sambil memukul sesuatu, (4) komplementer, yaitu dimaksudkan untuk melengkapi makna pesan verbal, (5) subtitusi, yaitu menggantikan pesan verbal, seperti menyatakan pujian dengan cara mengacungkan jempol tanpa menggunakan kata-kata.

\section{Etika Tutur Bahasa Indonesia}

Pada dasarnya, etika bahasa adalah suatu kaidah normatif penggunaan bahasa yang merupakan pedoman umum dan disepakati oleh masyarakat pengguna bahasa 
bahwa cara yang demikian itu diakui sebagai bahasa yang sopan, hormat, dan sesuai dengan tata nilai yang berlaku dalam masyarakat bahasa yang bersangkutan.

Secara khusus, Sukatman (2012) menjelaskan sejumlah aturan tutur dasar bahasa Indonesia yang perlu dipatuhi agar tuturan komunikasi terasa sopan. Aturan dasar yang dimaksud antara lain: (1) sikap terbuka dan bersahabat, (2) pertimbangan tabu bahasa, (3) penggunaan bahasa ilmiah, (4) penghalusan bahasa, (5) penggunaan ungkapan normatif khusus, (6) penggunaan pronomina secara tepat, (7) pemilihan kata yang bernilai rasa lebih halus, dan (8) penggunaan bahasa tubuh secara tepat.

\section{Sikap Terbuka dan Bersahabat}

Sikap terbuka untuk bisa mendengarkan keluhan dari siapa saja dalam masyarakat tutur bahasa Indonesia diakui sebagai sikap yang sopan dalam tindak tutur. Orang yang menolak diajak bicara atau tidak merespon pertanyaan dikesani sebagai orang yang sombong dan kurang sopan. Cara menanggapi keluhan atau pembicaraan dengan bersahabat juga diakui sebagai tatacara yang sopan dalam bertutur. Cara yang demikian akan membentuk suasana tutur yang kondusif, sehingga komunikasi berjalan secara baik.

\section{Pertimbangan Tabu Bahasa}

Dalam kegiatan tutur sehari-hari, penggunaan kata tertentu perlu dihindari karena nilai rasanya tidak sesuai. Jika dipaksakan dipakai biasanya menimbulkan kesan jorok, vulgar, dan tidak sopan. Kelompok kata pada kolom yang kedua apabila dipakai akan terasa lebih sopan jika dibandingkan dengan kelompok kata pada kolom pertama.

Perhatikan kelompok kata di bawah.

$\begin{array}{ll}\text { Bentuk tabu } & \text { Bentuk sopan } \\ \text { kakus } & \text { kamar kecil } \\ \text { pelacur } & \text { tunasusila } \\ \text { berak } & \text { buang air besar } \\ \text { kencing } & \text { buang air kecil }\end{array}$

\section{Penggunaan Bahasa Ilmiah}

Kesopanan tutur bisa diwujudkan dengan menggunakan kata-kata ragam ilmiah, karena ragam keseharian bernilai rasa kurang baik.

Perhatikan kata-kata di bawah. 
Bentuk Tabu Bentuk Ilmiah (Sopan)

air kencing urine

ayan epilepsi

dipotong diamputasi

mencret diare

\section{Penghalusan Bahasa (Eufemisme)}

Untuk bertutur secara sopan, masyarakat bahasa Indonesia sering menghaluskan kata-kata yang dianggap kasar. Penghalusan tersebut dilakukan dengan cara mencari padanannya yang secara semantis relatif bersinonim dan bernilai rasa lebih santun. Penggunaan bentuk halus tersebut berfungsi untuk menghindari kesan tidak sopan, salah paham, dan ketersinggungan. Gejala penghalusan kata-kata ini dikenal dengan gaya eufemisme.

Perhatikan kelompok kata berikut.

Bentuk Kasar Bentuk Halus (Sopan)

bodoh kurang cerdas

miskin prasejahtera

dipecat di-PHK

cacat kurang sempurna

\section{Penggunaan Ungkapan Normatif Khusus}

Ada sejumlah ungkapan khusus dalam bahasa Indonesia, yang apabila digunakan dalam bertutur akan terasa sopan. Ungkapan khusus tersebut dapat menghindarkan pembicara dari kesan mendikte, asal menyuruh, memandang rendah orang yang dikenai tindakan, dan "sok kuasa".

Perhatikan contoh berikut.

- Maaf, bisa mengganggu sebentar, mau minta rekomendasi.

- Dimohon (dengan hormat) untuk menunggu giliran.

- Sebaiknya Ibu pulang, masalahnya sudah selesai.

Kalimat-kalimat di atas terasa lebih sopan jika dibandingkan dengan kalimat di bawah ini, walaupun ide dasarnya relatif sama.

- Mau minta rekomendasi.

- Tunggu giliran.

- Pulanglah, urusanmu sudah selesai. 


\section{Penggunaan Pronomina}

Kata ganti orang (pronomina) pada kolom yang pertama biasa dipakai untuk orang yang setara umur, jabatan, status sosial, dan telah akrab. Pronomina pada kolom kedua biasa dipakai untuk berbicara dengan orang yang perlu dihormati secara proporsional dan tidak terlalu feodal.

Perhatikan kelompok kata di bawah.

$\begin{array}{lll}\text { Kata Ganti Orang } & \text { Bentuk Biasa } & \text { Bentuk Halus (Sopan) } \\ \text { pertama } & \text { aku } & \text { saya, hamba } \\ \text { kedua } & \text { kamu, engkau } & \text { Anda, saudara, tuan } \\ \text { ketiga } & \text { dia, mereka } & \text { beliau }\end{array}$

\section{Pemilihan Kata yang Bernilai Rasa Lebih Halus}

Dalam bertutur, pilihan kata yang bernilai rasa halus sangat diperlukan. Dalam bahasa Indonesia ada kata yang ide pokoknya sama tetapi nilai rasanya sangat berbeda. Kata-kata tertentu hanya cocok digunakan bagi "penjahat" dan bahkan hanya cocok untuk binatang saja.

Perhatikan kelompok kata berikut.

$\begin{array}{ll}\text { Bentuk Kasar } & \text { Bentuk Halus (Sopan) } \\ \text { Bunting } & \text { Hamil } \\ \text { Beranak } & \text { Melahirkan } \\ \text { Melahap } & \text { Makan, santap siang } \\ \text { Berkicau } & \text { Bersenandung }\end{array}$

\section{Penggunaan Bahasa Tubuh secara Tepat}

Dalam kegiatan tutur bahasa Indonesia sehari-hari di masyarakat lazim diikuti oleh bahasa tubuh (gestur) secara proporsional. Penggunaan bahasa tubuh tersebut biasanya mempertimbangkan mitra tutur. Apabila berbicara dengan orang yang perlu dihormati atau umurnya lebih tua, akan terkesan kurang sopan jika berbicara sambil berkacak pinggang, membuang muka, meletakkan kaki di atas meja, menunjuknunjuk mitra tuturnya dengan jari, dan sebagainya.

Pada masyarakat tertentu (suku tertentu) dalam berbahasa Indonesia sering menggunakan gestur dari kultur lokal yang berasal dari bahasa daerah yang bersangkutan. Misalnya, masyarakat Bugis dan sebagian suku lain dalam bertutur akan dinilai lebih sopan apabila misalnya menaruh kedua tangan di depan, berjalan 
dengan agak membungkuk apabila lewat di depan orang yang lebih tua (menghormati), dan sebagainya.

\section{Daftar Rujukan}

Arsyad, M. dkk. (1988). Pembicaraan Kemampuan Berbicara Bahasa Indonesia. Surabaya: Erlangga.

Azhim, S. (2002). Membimbing Anak Terampil Berbahasa. Jakarta: Gema Insani. Cangara, H. (2002). Pengantar Ilmu Komunikasi. Jakarta: Raja Grafindo Persada. Halim, A. dkk. (1997). Teknik Pengajaran Berbicara. Jakarta: Djambatan.

King, L. (2004). Seni Berbicara. Jakarta: Gramedia Pustaka Utama. Latipun. (1996). Psikologi Konseling. Malang: UMM Press.

Mansyur, U. (2016). Bahasa Indonesia dalam Belitan Media Sosial: Dari CabeCabean Hingga Tafsir Al-Maidah 51. http://doi.org/10.17605/OSF.IO/7VPJH Muhammad, A. (1995). Komunikasi Organisasi. Jakarta: Bumi Aksara.

Sukatman. (2012). Budaya Tutur Bahasa Indonesia dan Kontribusinya bagi Pendidikan Etika di Sekolah Dasar. Jurnal Ilmu Pendidikan Dasar, 1(2), 154165.

Taufik, T. (2006). Kesepadanan Komunikasi Verbal dan Unsur Nonverbalnya dalam Interaksi Guru-Siswa di Kelas 1 Sekolah Dasar Kartika Padang. Disertasi. Malang: PPs Universitas Negeri Malang.

Winataputra. (2007). Pengembangan Keterampilan Berbicara. Jakatra: Depdikbud. 